OPEN ACCESS

Edited by:

Youji Wang,

Shanghai Ocean University, China

Reviewed by:

Shannon McMahon

James Cook University, Australia Michael D. Jarrold,

James Cook University, Australia

${ }^{*}$ Correspondence:

Liu Guangxu

guangxu_liu@zju.edu.cn

Specialty section:

This article was submitted to

Aquatic Physiology,

a section of the journal

Frontiers in Physiology

Received: 14 March 2018 Accepted: 24 October 2018 Published: 20 November 2018

Citation:

Jiahuan $R$, Wenhao $S$, Xiaofan $G$,

Wei S, Shanjie Z, Maolong H, Haifeng W and Guangxu L (2018) Ocean Acidification Impairs Foraging Behavior by Interfering With Olfactory

Neural Signal Transduction in Black Sea Bream, Acanthopagrus schlegelii. Front. Physiol. 9:1592.

doi: 10.3389/fphys.2018.01592

\section{Ocean Acidification Impairs Foraging Behavior by Interfering With Olfactory Neural Signal Transduction in Black Sea Bream, Acanthopagrus schlegelii}

\author{
Rong Jiahuan', Su Wenhao', Guan Xiaofan', Shi Wei', Zha Shanjie', He Maolong"2, \\ Wang Haifeng ${ }^{1}$ and Liu Guangxu ${ }^{1 *}$ \\ ${ }^{1}$ College of Animal Science, Zhejiang University, Hangzhou, China, ${ }^{2}$ Lucta (Guangzhou) Flavours Co., Ltd., Guangzhou, \\ China
}

In recent years, ocean acidification $(\mathrm{OA})$ caused by oceanic absorption of anthropogenic carbon dioxide $\left(\mathrm{CO}_{2}\right)$ has drawn worldwide concern over its physiological and ecological effects on marine organisms. However, the behavioral impacts of $\mathrm{OA}$ and especially the underlying physiological mechanisms causing these impacts are still poorly understood in marine species. Therefore, in the present study, the effects of elevated $\mathrm{pCO}_{2}$ on foraging behavior, in vivo contents of two important neurotransmitters, and the expression of genes encoding key modulatory enzymes from the olfactory transduction pathway were investigated in the larval black sea bream. The results showed that larval sea breams (length of $4.71 \pm 0.45 \mathrm{~cm}$ ) reared in $\mathrm{pCO}_{2}$ acidified seawater $(\mathrm{pH}$ at 7.8 and 7.4) for 15 days tend to stall longer at their acclimated zone and swim with a significant slower velocity in a more zigzag manner toward food source, thereby taking twice the amount of time than control $(\mathrm{pH}$ at 8.1) to reach the food source. These findings indicate that the foraging behavior of the sea bream was significantly impaired by ocean acidification. In addition, compared to a control, significant reductions in the in vivo contents of $\gamma$-aminobutyric acid (GABA) and Acetylcholine (ACh) were detected in ocean acidification-treated sea breams. Furthermore, in the acidified experiment groups, the expression of genes encoding positive regulators, the olfaction-specific G protein (Golf) and the G-protein signaling 2 (RGS2) and negative regulators, the G protein-coupled receptor kinase (GRK) and arrestin in the olfactory transduction pathway were found to be significantly suppressed and up-regulated, respectively. Changes in neurotransmitter content and expression of olfactory transduction related genes indicate a significant disruptive effect caused by OA on olfactory neural signal transduction, which might reveal the underlying cause of the hampered foraging behavior.

Keywords: ocean acidification, black sea bream, foraging behavior, olfactory transduction, neurotransmitters 


\section{INTRODUCTION}

Since the industrial revolution, anthropogenic activities such as cement production and the utilization of fossil fuels have released large amounts of carbon dioxide $\left(\mathrm{CO}_{2}\right)$ into the atmosphere, resulting in a substantial rise of atmospheric $\mathrm{CO}_{2}$ partial pressure $\left(p \mathrm{CO}_{2}\right)$ (Widdicombe and Spicer, 2008). According to the predictions of the Intergovernmental Panel on Climate Change (IPCC), the atmospheric $\mathrm{CO}_{2}$ concentration has increased from a pre-industrial level of approximately $280 \mathrm{ppm}$ to a present level of approximately 400 ppm (Team et al., 2014). An enormous amount of anthropogenic $\mathrm{CO}_{2}$ (approximately $1 / 4$ to $1 / 3$ ) has been absorbed by the ocean, and while this mitigates the growth of atmospheric $\mathrm{CO}_{2}$ concentration, it leads to ocean acidification (OA), the decrease in the $\mathrm{pH}$ of surface seawater induced by elevated $p \mathrm{CO}_{2}$ (Caldeira and Wickett, 2003; Sabine et al., 2004). Compared to pre-industrial levels, the current $\mathrm{pH}$ of surface seawater has decreased by 0.1 units and is predicted to drop by another 0.3 to 0.4 units by the end of 21 st century and 0.7 to 0.8 units by the year of 2300 (Kleypas et al., 1999; Sabine et al., 2004; Orr et al., 2005).

In recent years, OA has drawn worldwide concern over its physiological and ecological effects on marine organisms, and it has been shown that a series of physiological processes, such as fertilization (Parker et al., 2009; Sewell et al., 2013; Shi et al., 2017a,b), embryonic development (Egilsdottir et al., 2009; Przeslawski et al., 2015; Gravinese, 2017), metabolism (Lannig et al., 2010; Carter et al., 2013; Kroeker et al., 2013; Wittmann and Pörtner, 2013; Zhao et al., 2017a,b), immunity (Bibby et al., 2008; Liu et al., 2016; Wang et al., 2016; Su et al., 2017, 2018), and behavior (Clements and Hunt, 2015; Nagelkerken and Munday, 2016; Peng et al., 2017), in various marine species can be affected by ocean acidification. In addition to altering $\mathrm{pH}, \mathrm{OA}$ also reduces the availability of carbonate ions by decreasing the saturation state of calcium carbonate $\left(\mathrm{CaCO}_{3}\right)$ (Kleypas et al., 1999). Therefore, most studies investigating the physiological effects of OA have been conducted with calcifying organisms such as corals, echinoderms, and bivalve mollusks (Fine and Tchernov, 2007; Havenhand et al., 2008; Gazeau et al., 2010; Reuter et al., 2011; Hofmann and Bischof, 2014; Bhadury, 2015; Segman et al., 2016). However, the effects of OA on other marine species such as fishes remain poorly understood to date.

In recent years, a series of studies have demonstrated that OA can impair the olfactory functions of a range of marine fish species (Munday et al., 2009, 2010, 2013; Dixson et al., 2010, 2015; Cripps et al., 2011; Ferrari et al., 2011; Devine et al., 2012; McMahon et al., 2018). Since a robust olfactory sense is essential for the survival of marine fishes to avoid predators, to look for suitable habitats, and to locate food sources, olfactory impairment caused by OA has profound impacts on marine fish species (Munday et al., 2009; Gardiner et al., 2014; Yopak et al., 2015). Furthermore, it has been suggested that the olfactory and behavioral impairments induced by elevated $p \mathrm{CO}_{2}$ levels are probably due to alterations in the function of neurotransmitters, which play a crucial role in the transduction of olfactory neural signals (Nilsson et al., 2012; Roggatz et al., 2016; Clements et al., 2017). In order to maintain an acid-base balance, marine species including fish and invertebrates accumulate $\mathrm{HCO}_{3}{ }^{-}$with compensatory reduction in $\mathrm{Cl}^{-}$in their plasma and tissues, which changes the transmembrane gradients of these anions and subsequently excites the GABA receptors (Baker et al., 2009; Esbaugh et al., 2012; Nilsson et al., 2012; Heuer and Grosell, 2014; Heuer et al., 2016). Since the abnormal olfactory preferences of fish can be rescued by gabazine, an antagonist of GABA receptor, the abnormal behavior under OA scenarios may partially attribute to the over-excitation of GABA receptors (Nilsson et al., 2012; Lai et al., 2015). Theoretically, since it is the binding of neurotransmitters with the corresponding receptors that trigger downstream behavioral and physiological regulations, changes in in vivo contents of neurotransmitters may offset or reinforce the impacts caused by alterations in their receptors. However, to the best of our knowledge, the direct impact of OA on the in vivo contents of neurotransmitters has yet to be investigated. Moreover, to generate olfactory neural signals, odor cues need to bind to corresponding receptors to trigger a cascade of cellular signaling events (Kaupp, 2010; Leduc et al., 2013). However, it remains unknown whether key molecules from the olfactory transduction cascade pathway will be affected by elevated $p \mathrm{CO}_{2}$. These paucities have put significant constrains to a better understanding on the physiological mechanisms underlying the behavioral impairment under OA scenarios.

Black sea bream, Acanthopagrus schlegelii, a euryhaline, omnivorous fish, is one of the major commercial fish species in the Asian Pacific (Ji et al., 2003; Ma et al., 2008). Well developed breeding and culture techniques make black sea bream a tractable fish species to address general questions such as the physiological mechanism causing behavioral impairments (Nip et al., 2003). In addition, it has been shown that seasonal variation and uneven food distribution in the ocean often causes periodic food insufficiency for black sea bream (Nip et al., 2003). Since olfaction is an essential physiological mechanism triggering foraging behavior, any disruption brought by environmental changes, such as ocean acidification, could subject black sea bream to malnutrition and subsequently lead to reduction in growth and survivor rates, which may further aggravate the decline of natural population caused by overfishing. Since little is known about the behavioral impacts and the physiological mechanisms behind the behavioral impairment of fish species under OA scenarios to date, the present study was conducted to determine whether the foraging behavior, in terms of the efficiency to detect olfactory cue of food, will be affected by nearfuture ocean acidification. More importantly we saught to explore whether the behavioral change detected, if any, may be due to an interfered olfactory signal transduction as reflected by the in vivo contents of neurotransmitters (GABA and $\mathrm{ACh}$ ) and the expression of key genes modulating olfactory signal transduction.

\section{MATERIALS AND METHODS}

\section{Ethics Statement}

This study is performed in accordance with the Animal Ethics Committee in the School of Medicine, Zhejiang University (ETHICS CODE Permit NO. ZJU2011-1-11-009Y, issued by the 
Animal Ethics Committee in the School of Medicine, Zhejiang University).

\section{Experimental Animals and Acclimation}

Since larvae are generally more susceptible to environmental changes and the recruitment of fish population can be significantly affected by their nutrition condition (Ishimatsu et al., 2004; Murphy et al., 2014), larval black sea breams were investigated in the present study. Larvae of regular size (length of $4.71 \pm 0.45 \mathrm{~cm}$, weight at $2.59 \pm 0.71 \mathrm{~g}$ ) from one spawning event using multiple parents were purchased from the Dongtou fish-breeding farm. The hatchery and rearing of these larvae were conducted in the open sea net cages with seawater at the ambient $\mathrm{pH}(\sim 8.10)$. Larvae sea breams were immediately transferred to the Qingjiang Station of Zhejiang Mariculture Research Institute, Wenzhou, China, in June 2017 and were acclimated for a week in a $500 \mathrm{~L}$ tank filled with $350 \mathrm{~L}$ of aerated, flowing seawater (temperature at $23.71 \pm 0.08^{\circ} \mathrm{C}, \mathrm{pH}$ at $8.10 \pm 0.01$, and salinity at $20.74 \pm 0.01$ ) before the experiment. During the acclimation period, black sea breams were fed with commercial pellet feed (diameter of $1.5 \mathrm{~mm}$ ) twice daily at $9 \mathrm{AM}$ and $5 \mathrm{PM}$. After the acclimation, healthy individuals without physical injury were used for the experiments.

\section{Ocean Acidification Treatment and Seawater Chemistry Monitoring}

According to the near-future OA scenarios predicted by the IPCC, $\mathrm{pH}$ levels of 8.1, 7.8, and 7.4 were employed to simulate the $\mathrm{pH}$ levels at present and in the years 2100 and 2250, respectively. According to the method of Zhao et al. (2017a), the stimulation of the acidified scenario was achieved by bubbling dry air or a mixture of carbon dioxide and dry air with different but constant percentages. Once the $\mathrm{pH}$ of each experimental tank reached equilibrium at corresponding desired $\mathrm{pH}$ through aeration, 90 sea bream individuals were randomly selected from the acclimation tank and equally assigned into 9 ( 3 treatments $\times 3$ replicates) experimental tanks (total volume of $50 \mathrm{~L}$ ) each containing $30 \mathrm{~L}$ of still seawater, pre-adjusted to the corresponding experimental $\mathrm{pH}$ values. The exposure was conducted in an air-conditioned indoor laboratory (temperature was set at $24^{\circ} \mathrm{C}$ ) with an exposure time of 15 days and the sea breams were fed with commercial pellet food at satiation rate twice daily (at 9 AM and 5 PM). An hour after feeding, seawater in each experimental tank was replaced with seawater pre-prepared at the corresponding experimental $\mathrm{pH}$ values. During the experiment, seawater of each tank was continuously aerated with the corresponding dry air or $\mathrm{CO}_{2}$-air mixture to maintain the stability of seawater carbonate chemistry.

To ensure that the chemical parameters of seawater in each tank were consistent throughout the entire experiment, $\mathrm{pH}$, salinity, and temperature were monitored daily and total alkalinity (TA) was determined once a week (Table 1). The $\mathrm{pH}_{\mathrm{NBS}}$ of each trial was measured by a $\mathrm{pH}$ meter (PB-10, Sartorius) and calibrated with NBS standard buffers. Salinity was measured with a conductivity meter (Multi 3410, WTW) and a mercury thermometer gaged temperature. TA was determined using potentiometric titration (Anderson and Robinson, 1946) with an automatic titrator system (SMTitrino 702, Metrohm). Carbonate system parameters were calculated from the measured $\mathrm{pH}_{\mathrm{NBS}}$, salinity, temperature, and TA values using the opensource program CO2SYS (Pierrot et al., 2006), with the constants supplied by Mehrbach et al. (1939) and refitted by Dickson and Millero (1987) and the $\mathrm{KSO}_{4}$ dissociation constant from Dixson et al. (2010).

\section{Foraging Behavior Experiments and Video Analysis}

Foraging behavior experiments were performed following published methods with modifications (Ferrari et al., 2012; Dodd et al., 2015; Pistevos et al., 2015). After exposure to corresponding $p \mathrm{CO}_{2}$ levels for 15 days and then food deprivation for $24 \mathrm{~h}, 5$ black sea bream individuals were randomly selected from each experimental tank and transferred to one end of a white plastic tray $(105 \times 80 \times 30 \mathrm{~cm})$ containing $100 \mathrm{~L}$ of sand-filtered still seawater. Since it has been suggested that the behavioral effects of OA will last in fish individuals for 1 or 2 days and the $\mathrm{pH}$ of testing sea water will not affect the behavioral responses observed (Munday et al., 2010, 2016), seawater at ambient pH 8.1 was used for the behavioral experiment in the present study. The 5 sea bream individuals were tested simultaneously as one replicate in the analysis. Individuals were allowed to acclimate for $30 \mathrm{~s}$ before the introduction of commercial food pellets $(50.10 \pm 0.81 \mathrm{~g})$, placed approximately $100 \mathrm{~cm}$ away from the acclimation area, at the other end of the tray. The food pellets were held in a glass petri dish with an opaque white cover with holes on the top, a design that allows the dispersal of olfactory cues but prevents visual detection of the food. The plastic baffle plate, which was used to restrain the fish in the acclimation area before the assay, was removed and video data of the foraging behavior was collected with an HD digital video camera (T90, Aigo ${ }^{\circledast}$, China) 3 min after the food was introduced. Three replicates were performed for each experimental group and fish tested were discarded to ensure that each individual was only tested once. The curvilinear swimming velocity (VCL) used to approach food source, the linearity (LIN) and wobble (WOB) of fish swimming path, and the time taken to leave the acclimation area and reach the food were determined using the opensource software ImageJ (National Institutes of Health, Bethesda, Maryland, United States) following the method described by Wilsonleedy and Ingermann (2007) and Shi et al. (2017a).

\section{Content Estimation of Neurotransmitters}

After 15-day exposure to corresponding $\mathrm{pCO}_{2}$ levels, 6 individuals were randomly selected from each experimental treatment tank and dissected on ice. Brain tissue of each individual was carefully removed and used for the determination of in vivo GABA and $\mathrm{ACh}$ contents using commercial ELISA kits (MLBIO biotechnology Co., Ltd., Shanghai, China) following the manufacturer's instructions. After weighing, samples were homogenized in ice-cold PBS (0.01 M, pH 7.4) followed by centrifugation at $2000 \mathrm{rpm}$ for $20 \mathrm{~min}$ at $4^{\circ} \mathrm{C}$. Twenty microliter of the supernatant was mixed with $80 \mu \mathrm{L}$ working reagent containing a chromogenic reagent. After incubation at room 
TABLE 1 | Seawater chemical parameters during the 15-day incubation experiment for the control and $p \mathrm{CO}_{2}$ acidified groups (mean $\pm \mathrm{SE}$ ).

\begin{tabular}{|c|c|c|c|c|c|c|c|c|}
\hline \multirow[t]{2}{*}{ Target pH } & \multirow[t]{2}{*}{$\mathbf{T}\left({ }^{\circ} \mathrm{C}\right)$} & \multirow[t]{2}{*}{ Sal( $\% 0)$} & \multirow[t]{2}{*}{$\mathrm{pH}_{\mathrm{NBS}}$} & \multirow{2}{*}{$\begin{array}{c}\text { TA } \\
(\mu \mathrm{mol} / \mathrm{kg})\end{array}$} & \multirow{2}{*}{$\begin{array}{c}\mathrm{pCO}_{2} \\
(\mu \mathrm{atm})\end{array}$} & \multirow{2}{*}{$\begin{array}{c}\text { DIC } \\
(\mathrm{mmol} / \mathrm{kg})\end{array}$} & \multirow[t]{2}{*}{ 凡ara } & \multirow[t]{2}{*}{ 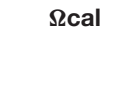 } \\
\hline & & & & & & & & \\
\hline pH 8.1 & $23.71 \pm 0.08$ & $20.74 \pm 0.01$ & $8.10 \pm 0.01$ & $2056.38 \pm 1.63$ & $356.84 \pm 4.39$ & $1879.78 \pm 6.22$ & $2.24 \pm 0.08$ & $3.36 \pm 0.13$ \\
\hline $\mathrm{pH} 7.8$ & $23.77 \pm 0.09$ & $20.61 \pm 0.01$ & $7.80 \pm 0.01$ & $2060.37 \pm 2.82$ & $776.96 \pm 8.22$ & $1984.42 \pm 4.75$ & $1.21 \pm 0.04$ & $1.97 \pm 0.07$ \\
\hline $\mathrm{pH} 7.4$ & $23.78 \pm 0.09$ & $20.73 \pm 0.01$ & $7.40 \pm 0.01$ & $2066.82 \pm 3.00$ & $2051.47 \pm 21.84$ & $2094.03 \pm 3.80$ & $0.51 \pm 0.02$ & $0.83 \pm 0.03$ \\
\hline
\end{tabular}

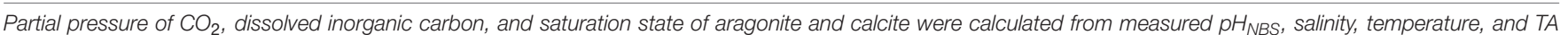

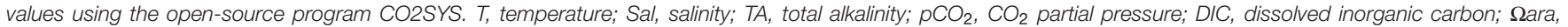
aragonite saturation state; $\Omega$ cal, calcite saturation state.

temperature for $20 \mathrm{~min}$, the absorption values at $450 \mathrm{~nm}$ were measured with a microplate reader (Thermo Multiskan Go, United States). The contents of GABA and ACh were subsequently determined using the corresponding standard curves.

\section{Expressions of Key Genes From Olfactory Transduction Pathway}

At the end of 15 days of $\mathrm{pCO}_{2}$ exposure, 6 individuals were randomly selected from each treatment tank and dissected on ice. The brain tissue of each individual was carefully removed and immediately frozen in liquid nitrogen. Total RNA was extracted from the tissue within two weeks of sampling using EASY spin Plus tissues/cells rapid RNA extraction kit (Aidlab, RN2802) following the method described (Peng et al., 2016). The quality and concentration of total RNA obtained were checked by gel electrophoresis and NanoDrop 1000 UV/visible spectrophotometer (Thermo Scientific), respectively. High-quality RNA samples were then reversely transcribed into first strand cDNA immediately using a M-MLV First Strand Kit (Invitrogen, C28025-032) following the manufacturer's protocols. Fresh cDNA samples or those stored in $-20^{\circ} \mathrm{C}$ less than 7 days were used for qPCR analysis. Quantitative PCRs with three technical replicates for each sample were performed in a CFX 96TM Real-Time System (Bio-Rad) in a total reaction volume of $10 \mu \mathrm{L}$ consisting of $5 \mu \mathrm{L} 2 \times$ Super Mix (Bio-Rad, 172-5201AP), $3 \mu \mathrm{L}$ double-distilled water, $0.5 \mu \mathrm{L}$ forward and reverse primer (10 $\mu \mathrm{M}$ each), and $1 \mu \mathrm{L}$ cDNA template. The amplification efficiency in terms of highest $R^{2}$ value was used to pre-optimize the amplification cycling parameters which included $95^{\circ} \mathrm{C}$ for $5 \mathrm{~min}$ followed by 40 cycles of $95^{\circ} \mathrm{C}$ for $20 \mathrm{~s}, 61^{\circ} \mathrm{C}$ for $20 \mathrm{~s}$, and $72^{\circ} \mathrm{C}$ for $20 \mathrm{~s}$. A melting curve analysis (MCA) was used to confirm specificity of the PCR products. In total, four genes coding for $\mathrm{G}$ protein subunit beta 1 (Golf), the regulator of G-protein signaling 2 ( $R G S 2$ ), G protein-coupled receptor kinase $2(G R K)$, and arrestin from the olfactory transduction pathway were investigated. The $18 \mathrm{~S}$ rRNA was used as a reference to calculate the relative expression levels of the genes investigated. All primers used in the present study were synthesized by Tsingke Biotech (Hangzhou, China). Sequence information of the primers is listed in Table 2.

\section{Statistical Analysis}

The effects of OA on the VCL, LIN, WOB approach to food source, the time taken for individuals to leave the acclimation
TABLE 2 | Primer sequences for the genes investigated and the internal reference 18S rRNA ( $F$ and $R$ after the dash line in the primer name indicate forward and reverse primers, respectively).

\begin{tabular}{lll}
\hline Primers & Sequence $\mathbf{( 5}^{\prime}$ to $\mathbf{3}^{\prime}$ ) & Accession no. \\
\hline 18S-F & GCCAAGTAGCATATGCTTGTCT & GU017319 \\
18S-R & AGACTTGCCTCCAATGGATCC & \\
Golf-F & GTCGGAGCATTATCATTCA & MH370475 \\
Golf-R & GGTAGCGTTGGAGATAGAG & \\
RGS2-F & CCTCAAGTCCGAGTTCTG & MH294433 \\
RGS2-R & CTCTGGATGATGGCATTCT & \\
GRK-F & GTCGGTACTCATGGTTACA & MH155243 \\
GRK-R & GGTCTTGTGCTGTCTGAA & \\
Arrestin-F & TCTACATCTCCACCTTCCA & MH141554 \\
Arrestin-R & CCTCTTGTGATCTTCTCTTC & \\
\hline
\end{tabular}

area (latency time) and reach the food (response time), and the in vivo contents of neurotransmitters of black sea bream were analyzed using a linear mixed effects model with the treatment tank as a random variable using " $\mathrm{R}$ " statistical package lme4 (Bates, 2010; Bates et al., 2015). Expression levels of the genes investigated were compared to that of the control with the Duncan multiple range tests (Tallarida and Murray, 1987) using SPSS19.0. A p-value less than 0.05 was considered a statistically significant difference for all the statistical analyses.

\section{RESULTS}

\section{Effect of Ocean Acidification on Foraging Behavior}

Exposure to elevated $p \mathrm{CO}_{2}$ for 15 days exerted a significant negative impact on the foraging behavior of black sea breams by reducing VCL and LIN whereas increasing latency time, response time, and WOB (Figure 1, $p<0.05$ ). Black sea breams raised in acidified seawater approached food pellets at significantly slower speeds, with reduction of $21.32 \%$ at $\mathrm{pH} 7.8$ and $35.72 \%$ at $\mathrm{pH}$ 7.4 , respectively, compared to that of the control (Figure 1A, $\left.F_{(2,8)}=54.1714, p=0.0007\right)$. Though no significant difference was detected for treatment groups at $\mathrm{pH} 7.8$, the time taken for individuals to reach the food source and leave the acclimated area were significantly increased for sea breams in $\mathrm{pH} 7.4$, which were approximately 2.34 and 3.46 times higher than that of the control (Figures 1B,E, $F_{(2,8)}=9.03568, p=0.0299$ and $F_{(2,8)}=63.51385$, 


\section{A}

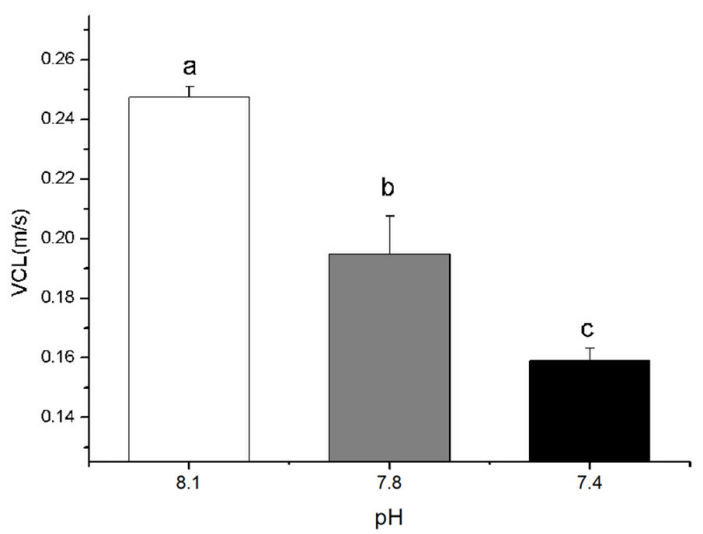

C

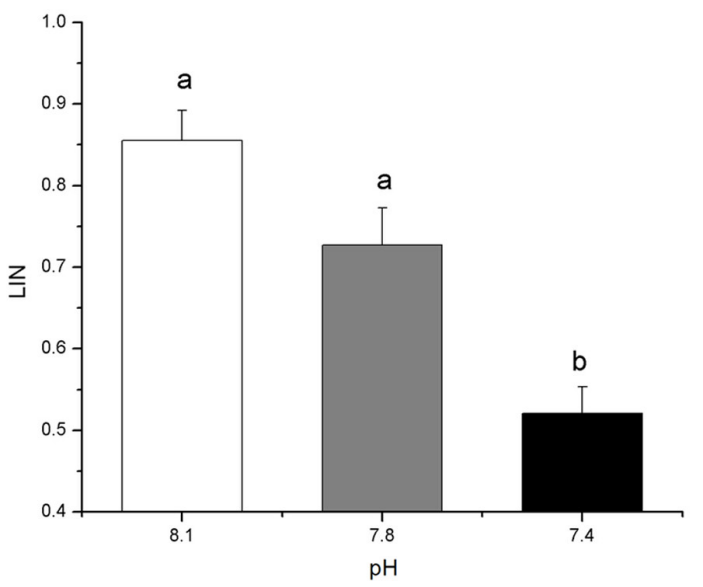

E

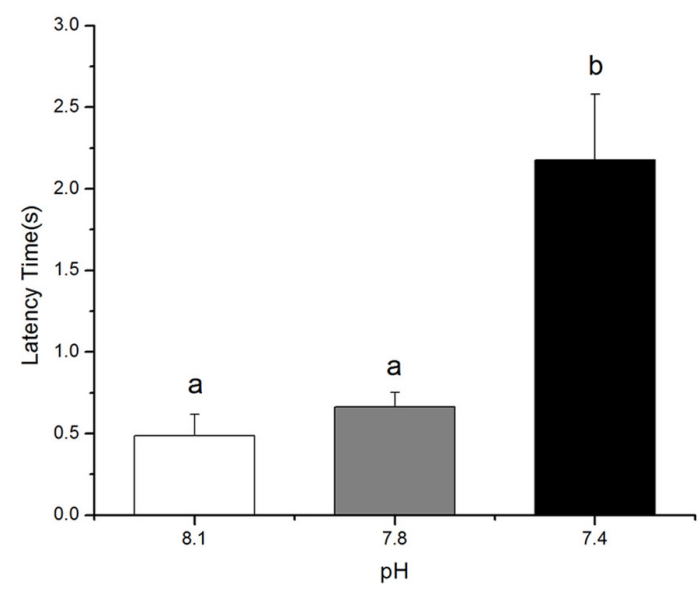

B

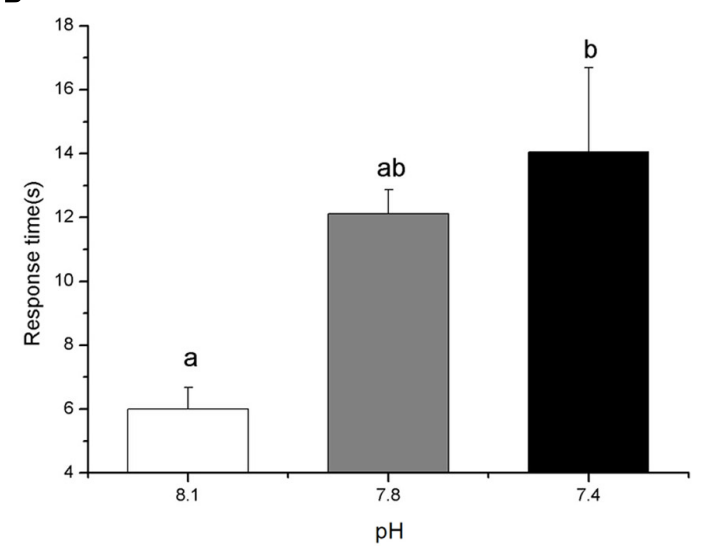

D

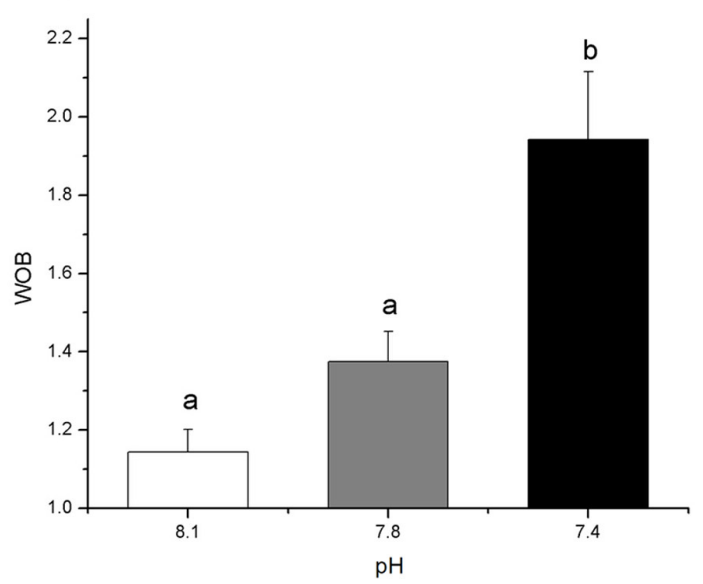

FIGURE 1 | The curvilinear velocity (VCL, A), the response time (time it took for individuals to reach the food source, B), the linearity (LIN) of swimming path (C), the wobble (WOB) of swimming path (D), and the latency time (time it took for individuals to leave the acclimated area, E) of black sea breams after 15 days exposure to the control or $\mathrm{pCO}_{2}$ acidified seawater at $\mathrm{pH} 8.1,7.8$, and 7.4, respectively. All data were presented as the means \pm SEM and groups not sharing the same superscripts are significantly different from each other at $p<0.05$.

$p=0.0005)$, respectively. Similarly, though no difference was observed for $\mathrm{pH} 7.8$ treatment group, treatment in $\mathrm{pH} 7.4$ led to significant changes in LIN and WOB of the individuals, with a decrease of $39.12 \%$ and an increase of $69.94 \%$ of the control (Figures 1C,D, $F_{(2,8)}=31.1332, p=0.0025$ and $F_{(2,8)}=19.4920$, $p=0.0069)$, respectively. 


\section{Effect of Ocean Acidification on the in vivo Contents of GABA and $\mathrm{ACh}$}

The in vivo contents of GABA and $\mathrm{ACh}$ in the brains of black sea breams were significantly reduced after 15 days exposure to elevated $\mathrm{pCO}_{2}$. Compared to that of the control, the GABA contents in individuals in $p \mathrm{CO}_{2}$ acidified seawater declined by approximately $21.55 \%$ at $\mathrm{pH} 7.4$ and $13.14 \%$ at pH 7.8 (Figure 2A, $F_{(8,26)}=14.4347, p=0.0126$ ). Similarly, the $\mathrm{ACh}$ contents for treatment groups at $\mathrm{pH} 7.4$ and 7.8 were approximately 40.54 and $20.32 \%$ of that of the control, respectively (Figure 2B, $F_{(8,26)}=15.4873, p=0.0110$ ).

\section{Effects of Ocean Acidification on the Expressions of Genes From the Olfactory Transduction Pathway}

The relative expressions of genes under investigation from the olfactory transduction pathway were significantly $(p<0.05)$ altered in black sea breams after 15 days exposure to acidified

A

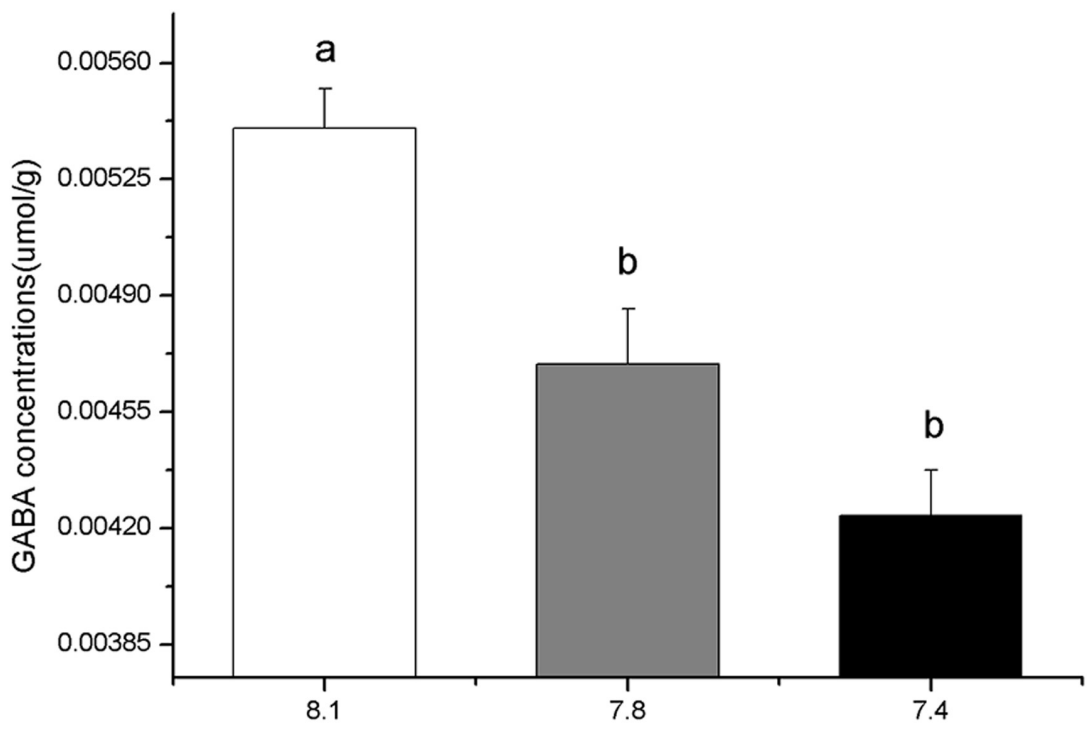

B

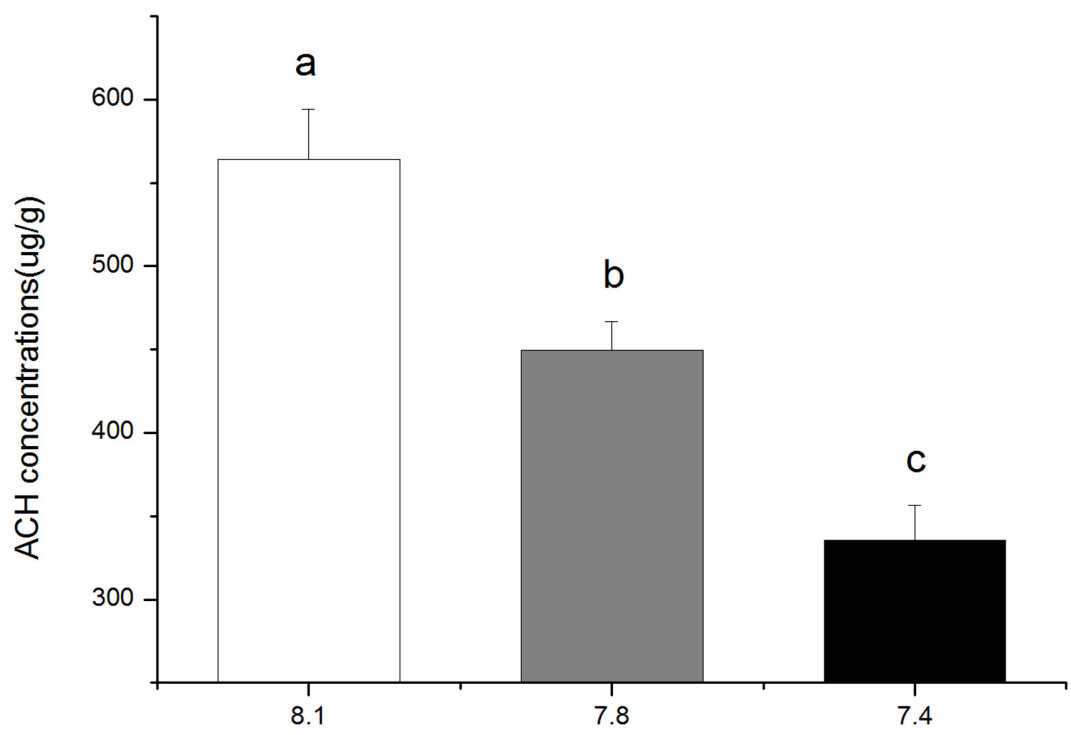

FIGURE 2 | The in vivo contents of GABA (A) and the in vivo contents of ACh (B) in black sea breams exposed to 15 days of control or $p \mathrm{CO}_{2}$ acidified seawater at $\mathrm{pH}$ 8.1, 7.8, and 7.4, respectively. All data were presented as the means \pm SEM and groups not sharing the same superscripts are significantly different from each other at $p<0.05$. 
seawater. Compared to the control, a significant down-regulation of the genes encoding Golf and RGS2, which positively regulate olfactory transduction, was detected in the $p \mathrm{CO}_{2}$ elevated experimental groups. The relative expressions of genes encoding RGS2 declined by $36.92 \%$ at $\mathrm{pH} 7.8$ and $63.04 \%$ at $\mathrm{pH} 7.4$ (Figure 3A, $F_{(8,26)}=32.85369, p=0.0023$ ), respectively, whereas Golf expression decreased by approximately $32.62 \%$ and $60.77 \%$ at $\mathrm{pH} 7.8$ and 7.4 , respectively (Figure 3B, $\left.F_{(8,26)}=33.18895, p=0.0022\right)$. In contrast, the expression of the genes encoding GRK and arrestin, two negative modulators for olfactory transduction, was significantly induced in individuals raised in acidified seawater, except for the expression of the genes encoding arrestin at $\mathrm{pH}$ 7.8. Specifically, the relative expressions of arrestin for treatment groups at $\mathrm{pH} 7.8$ and 7.4 increased by circa 58.03 and $142.93 \%$, respectively (Figure 3C, $\left.F_{(8,26)}=22.13905, p=0.0053\right)$. Expression of $G R K$ increased by roughly $60.78 \%$ for $\mathrm{pH} 7.8$ treatment group and $85.11 \%$ for $\mathrm{pH} 7.4$ treatment group (Figure 3D, $F_{(8,26)}=2.67412$, $p=0.1609)$.

\section{DISCUSSION}

Results obtained in the present study revealed that under future OA scenarios, black sea bream may swim in a more zigzag manner at a lower velocity and take a longer time locating food sources. Though inconsistent results have been reported in juvenile anemone fish, Amphiprion melanopus (Nowicki et al., 2012), our findings are comparable to most previous reports conducted in a range of other fish species. For instance, it took approximately 4 times longer for the shark Heterodontus portusjacksoni reared under elevated $\mathrm{pCO}_{2}$ at $\sim 1000 \mu \mathrm{atm}$ for approximately 36 days in mesocosms to locate their prey through olfaction, as compared to controls (Pistevos et al., 2015). Similarly, it was shown that several days exposure to acidified seawater $\left(p \mathrm{CO}_{2}\right.$ at $\left.600 \mu \mathrm{atm}\right)$ significantly altered the feeding behavior of the brown dottyback, Pseudochromis fuscus. This may result from olfactory impairment since the brown dottyback, after exposure to elevated $\mathrm{pCO}_{2}(600$ and $950 \mu \mathrm{atm})$, spent approximately $20 \%$ less time in a water

\section{A}

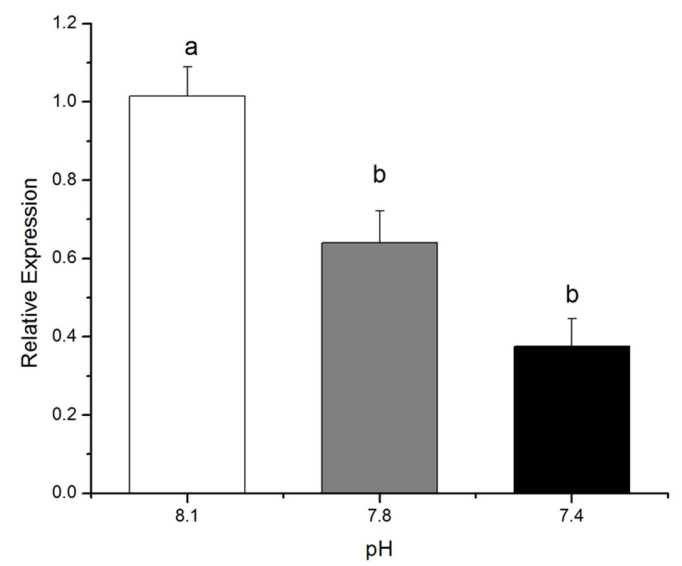

C

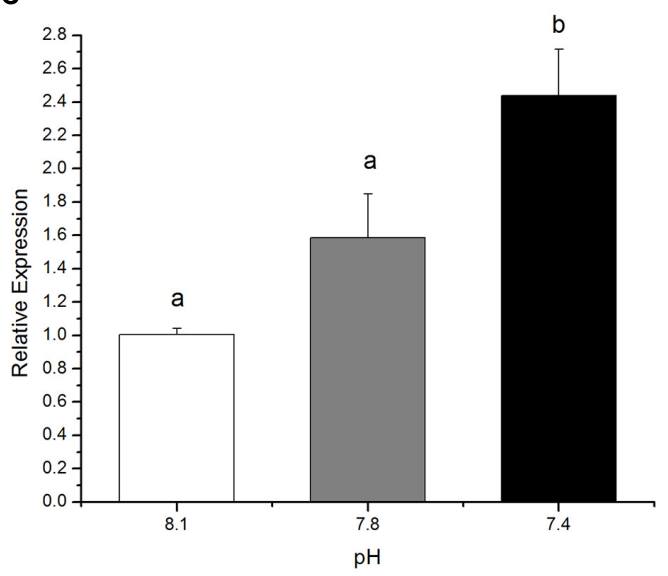

B

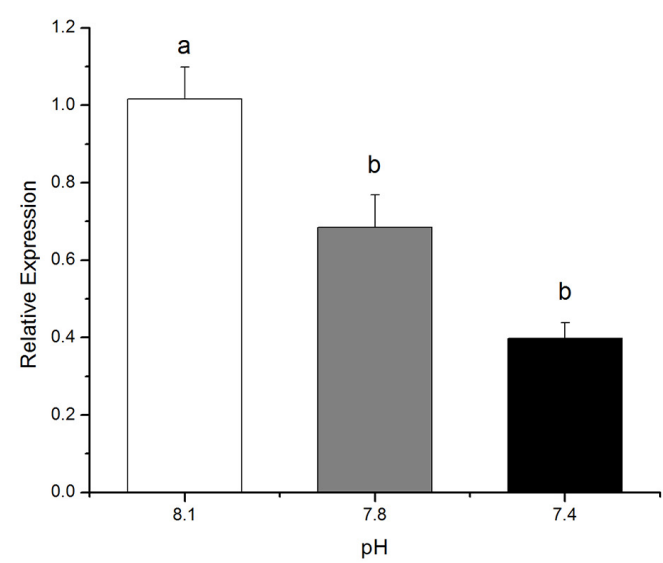

D

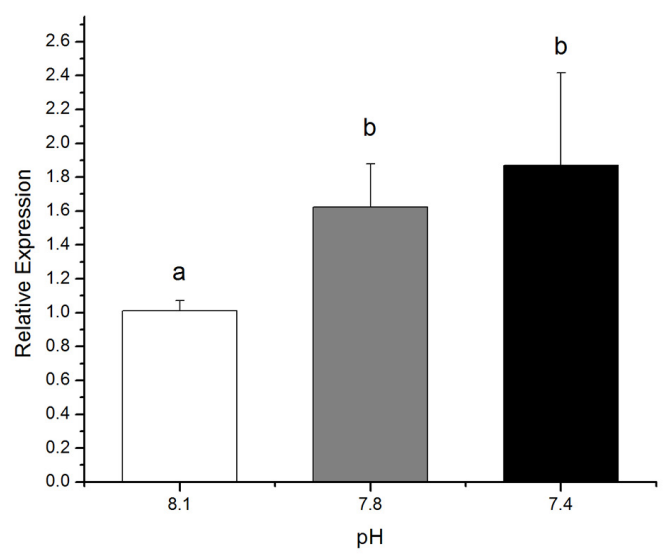

FIGURE 3 | The expression of genes encoding RGS2 (A), Golf (B) Arrestin (C), and GRK (D), after 15 days exposure to the control or $p \mathrm{CO}_{2}$ acidified seawater at $\mathrm{pH} 8.1,7.8$, and 7.4 , respectively. All data were presented as the means \pm SEM and groups not sharing the same superscripts are significantly different from each other at $p<0.05$. 
stream containing prey odor compared with controls (Cripps et al., 2011). Consequently, the impairment in foraging efficiency detected in the present study may leave black sea breams more vulnerable to malnutrition under future OA scenarios, especially when the potential food species may also suffer effects from similar high partial pressure of $\mathrm{CO}_{2}$ environment (Comeau et al., 2009; Saderne and Wahl, 2012).

Olfactory transduction is crucial for triggering behavioral responses, such as foraging, to odor cues (Arvedlund and Takemura, 2006). Within the compact cilia of the olfactory receptor neurons (ORNs), a cascade of enzymatic activity transduces the binding of an odorant molecule to a receptor into an electrical signal that can be transmitted to the brain (Kaupp, 2010). This process is initiated by the binding of an odorant to the olfactory receptor $(O R)$, which activates the olfactionspecific $\mathrm{G}$ protein (Golf) and subsequently the adenylyl cyclase type III $(A C I I I)$, the olfactory cyclic nucleotide-gated channel (CNGC; composed of one B1b, one A4 and two A2 subunits), and the $\mathrm{Ca}^{2+}$-activated $\mathrm{Cl}^{-}$channel $(\mathrm{CaCC})$ through a cascade reaction. Activation of these channels elicits the influx of $\mathrm{Ca}^{2+}$, $\mathrm{Na}^{+}$and the exodus of $\mathrm{Cl}^{-}$thereby generating an electrical signal, and the depolarization of the plasma membrane. This process is negatively regulated through inhibition of the $O R$ by the phosphorylation of the GRK, arrestin, and protein kinase A $(P K A)$, which activates ion exchangers and initiates the release of
$\mathrm{Ca}^{2+}$ and $\mathrm{K}^{+}$and the influx of $\mathrm{Na}^{+}$. In addition, the G-protein signaling 2 (RGS2) positively modulates olfactory transduction in this process by inhibiting $A C I I I$ and subsequently downregulating the $P K A$, an inhibitor for the $O R$ (Firestein, 2001; Kato and Touhara, 2009; Kaupp, 2010; Peterlin et al., 2014). Therefore, in the present study, the results that acidification suppressed the expression of positive regulators (Golf and RGS2) while inducing negative regulators (GRK and arrestin) in the olfactory transduction pathway, indicate a significantly hampered olfactory transduction in response to elevated $p \mathrm{CO}_{2}$.

Responding to a threshold graded electrical potential, such as that generated by the olfactory transduction pathway, neurotransmitters are released into the synaptic cleft, where they bind to corresponding receptors and subsequently pass on the information to neighboring target cells. Therefore, both the neurotransmitters and their receptors are crucial for regulating physiological and behavioral responses of an organism to environmental variations (Nilsson et al., 2012; Clements et al., 2017; Peng et al., 2017). Currently, behavioral and olfactory impairment under simulated $\mathrm{OA}$ is thought to be caused by alteration of GABA receptor modulation of internal acid-base homeostasis (Nilsson et al., 2012; Chivers et al., 2014; Clements and Hunt, 2015; Regan et al., 2016; Schunter et al., 2016, 2018), leaving the potential impacts of neurotransmitter content largely overlooked. In addition, though it has been shown that

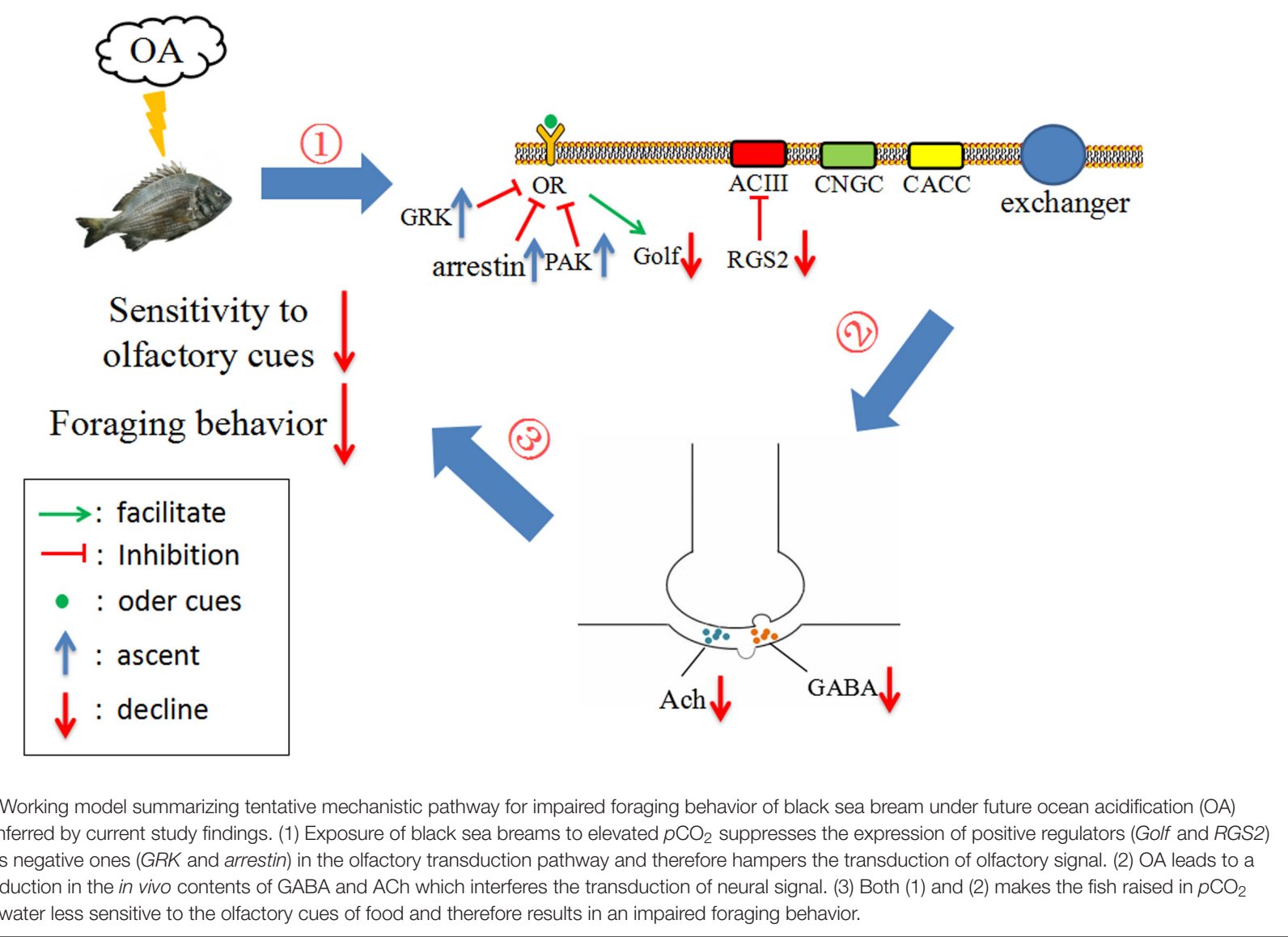


upon stimuli, both GABA and ACh will be released into mitral cells, where nerve cells located on the olfactory bulb receive information from the olfactory receptor, indicating essential roles of both GABA and ACh in transmitting olfactory neural signals (Elaagouby and Gervais, 1992; Liu et al., 2013; Borin et al., 2014; Tatti et al., 2014), little is known about the response of ACh to elevated $p \mathrm{CO}_{2}$. Therefore, the significant reduction in the in vivo contents of both GABA and ACh under elevated $p \mathrm{CO}_{2}$ detected in the present study not only suggested that ACh along with GABA may participate in the regulation of $\mathrm{OA}$ induced behavioral changes, but also indicated a significant interference in the olfactory neural signal transduction pathway in black sea breams under near-future OA scenarios (Figure 4). In addition, the binding of signal molecules to corresponding receptors could also be affected by OA (Roggatz et al., 2016), which may also contribute to the hampered olfactory signal transduction detected. However, this inference requires further experimental confirmation.

In recent years, increasing evidence showed that some marine species can acclimate to high levels of $\mathrm{CO}_{2}$ over time (Form and Riebesell, 2012; Miller et al., 2012; Parker et al., 2012; Dupont et al., 2013; Zhao et al., 2016, 2018). Currently there is still no evidence for within- or trans-generational acclimation of behavioral responses to $\mathrm{OA}$ in fishes, possibly due to limited plasticity of functioning neurotransmitters (Munday, 2014; Welch et al., 2014). Currently, it remains unclear whether and to what extent fishes will adapt to ocean acidification, however, preliminary research showing considerable individual variation in the expression of $\mathrm{CO}_{2}$-sensitive genes in fishes indicates there may be scope (Schunter et al., 2016, 2018).

In conclusion, we show that the foraging behavior of black sea breams was significantly impaired by exposure to

\section{REFERENCES}

Anderson, D. H., and Robinson, R. J. (1946). Rapid electrometric determination of alkalinity of sea water using glass electrode. Ind. Eng. Chem. 18, 767-769. doi: 10.1021/i560160a011

Arvedlund, M., and Takemura, A. (2006). The importance of chemical environmental cues for juvenile Lethrinus nebulosus, Forsskål (Lethrinidae, Teleostei) when settling into their first benthic habitat. J. Exp. Mar. Biol. Ecol. 338, 112-122. doi: 10.1016/j.jembe.2006.07.001

Baker, D. W., Matey, V., Huynh, K. T., Wilson, J. M., Morgan, J. D., and Brauner, C. J. (2009). Complete intracellular ph protection during extracellular $\mathrm{pH}$ depression is associated with hypercarbia tolerance in white sturgeon, Acipenser transmontanus. Am. J. Physiol. Reg. I 296, R1868-R1880. doi: 10.1152/ajpregu. 90767.2008

Bates, D., Machler, M., Bolker, B. M., and Walker, S. C. (2015). Fitting linear mixed-effects models using lme4. J. Stat. Softw. 67, 1-48. doi: 10.18637/jss.v067. i01

Bates, D. M. (2010). Ime4: Mixed-Effects Modeling with R. Berlin: Springer.

Bhadury, P. (2015). Effects of ocean acidification on marine invertebrates-a review. Indian J. Geo-Mar. Sci. 44, 1-11.

Bibby, R., Widdicombe, S., Parry, H., Spicer, J., and Pipe, R. (2008). Effect of ocean acidification on the immune response of the blue mussel, Mytilus edulis. Aquat. Biol. 2, 67-74. doi: 10.3354/ab00037

Borin, M., Iseppe, A. F., Pignatelli, A., and Belluzzi, O. (2014). Inward rectifier potassium (Kir) current in dopaminergic periglomerular neurons of the mouse olfactory bulb. Front. Cell. Neurosci. 8:223. doi: 10.3389/fncel.2014.00223 elevated $\mathrm{pCO}_{2}$ levels in this study, which may result from a reduced sensitivity to olfactory cues due to interference in the transduction of olfactory neural signals. To the best of our knowledge, this is the first study demonstrating the physiological mechanism with respect to the olfactory signal transduction underlying the high $\mathrm{CO}_{2}$ induced olfactory impairment. The findings of the present study together with currently available data suggest the mechanism underlying $\mathrm{CO}_{2}$ induced behavioral impairment could be consequences of multiphysiological changes and therefore should be examined and interpreted comprehensively. The impaired foraging efficiency detected in the current study may have considerable implications for wild populations and therefore for fisheries and resource managers.

\section{AUTHOR CONTRIBUTIONS}

RJ, HM, WH, and LG contributed conception and design of the experimental plan. RJ, SuW, GX, ShW, and ZS performed the experiments. RJ, HM, and LG performed the statistical analysis and wrote the manuscript.

\section{FUNDING}

This work was funded by National Natural Science Foundation of China (No. 31672634), Open Fund of Key Laboratory of Marine Ecosystem and Biogeochemistry SOA (LMEB201708), and Open Fund of Key Laboratory of Eco-Environment and Disaster Preservation of Shandong, North China Sea Branch of SOA (No. 201704).

Caldeira, K., and Wickett, M. E. (2003). Oceanography: anthropogenic carbon and ocean pH. Nature 425:365. doi: 10.1038/425365a

Carter, H. A., Ceballos-Osuna, L., Miller, N. A., and Stillman, J. H. (2013). Impact of ocean acidification on metabolism and energetics during early life stages of the intertidal porcelain crab Petrolisthes cinctipes. J. Exp. Biol. 216, 1412-1422. doi: $10.1242 /$ jeb. 078162

Chivers, D. P., McCormick, M. I., Nilsson, G. E., Munday, P. L., Watson, S. A., Meekan, M. G., et al. (2014). Impaired learning of predators and lower prey survival under elevated $\mathrm{CO}_{2}$ : a consequence of neurotransmitter interference. Global Change Biol. 20, 515-522. doi: 10.1111/gcb.12291

Clements, J. C., Bishop, M. M., and Hunt, H. L. (2017). Elevated temperature has adverse effects on GABA-mediated avoidance behavior to sediment acidification in a wide-ranging marine bivalve. Mar. Biol. 164:56. doi: 10.1007/ s00227-017-3085-1

Clements, J. C., and Hunt, H. L. (2015). Marine animal behavior in a high $\mathrm{CO}_{2}$ ocean. Mar. Ecol. Prog. Ser. 536, 259-279. doi: 10.3354/ meps 11426

Comeau, S., Gorsky, G., Jeffree, R., and Teyssié, J. L. (2009). Key arctic pelagic mollusc (Limacina helicina) threatened by ocean acidification. Biogeosci. Discuss. 6, 2523-2537. doi: 10.5194/bgd-6-2523-2009

Cripps, I. L., Munday, P. L., and Mccormick, M. I. (2011). Ocean acidification affects prey detection by a predatory reef fish. PLoS One 6:e22736. doi: 10.1371/ journal.pone.0022736

Devine, B. M., Munday, P. L., and Jones, G. P. (2012). Rising $\mathrm{CO}_{2}$ concentrations affect settlement behavior of larval damselfishes. Coral Reefs 31, 229-238. doi: 10.1007/s00338-011-0837-0 
Dickson, A. G., and Millero, F. J. (1987). A comparison of the equilibrium constants for the dissociation of carbonic acid in seawater media. Deep Sea Res. A 34, 1733-1743. doi: 10.1016/0198-0149(87)90021-5

Dixson, D. L., Jennings, A. R., Atema, J., and Munday, P. L. (2015). Odor tracking in sharks is reduced under future ocean acidification conditions. Global Change Biol. 21, 1454-1463. doi: 10.1111/gcb.12678

Dixson, D. L., Munday, P. L., and Jones, G. P. (2010). Ocean acidification disrupts the innate ability of fish to detect predator olfactory cues. Ecol. Lett. 13, 68-75. doi: 10.1111/j.1461-0248.2009.01400.x

Dodd, L. F., Grabowski, J. H., Piehler, M. F., Westfield, I., and Ries, J. B. (2015). Ocean acidification impairs crab foraging behavior. Proc. Biol. Sci. 282, 1-9. doi: $10.1098 /$ rspb.2015.0333

Dupont, S., Dorey, N., Stumpp, M., Melzner, F., and Thorndyke, M. (2013). Longterm and trans-life-cycle effects of exposure to ocean acidification in the green sea urchin Strongylocentrotus droebachiensis. Mar. Biol. 160, 1835-1843. doi: 10.1007/s00227-012-1921-x

Egilsdottir, H., Spicer, J. I., and Rundle, S. D. (2009). The effect of $\mathrm{CO}_{2}$, acidified sea water and reduced salinity on aspects of the embryonic development of the amphipod Echinogammarus marinus, (Leach). Mar. Pollut. B. 58, 1187-1191. doi: 10.1016/j.marpolbul.2009.03.017

Elaagouby, A., and Gervais, R. (1992). Ach-induced long-lasting enhancement in excitability of the olfactory bulb. Neuroreport 3, 10-12. doi: 10.1097/00001756199201000-00002

Esbaugh, A. J., Heuer, R., and Grosell, M. (2012). Impacts of ocean acidification on respiratory gas exchange and acid-base balance in a marine teleost, Opsanus beta. J. Comp. Physiol. B 182, 921-934. doi: 10.1007/s00360-0120668-5

Ferrari, M. C. O., Dixson, D. L., Munday, P. L., Mccormick, M. I., Meekan, M. G., Sih, A., et al. (2011). Intrageneric variation in antipredator responses of coral reef fishes affected by ocean acidification: implications for climate change projections on marine communities. Global Change Biol. 17, 2980-2986. doi: $10.1111 / \mathrm{j} .1365-2486.2011 .02439 . \mathrm{x}$

Ferrari, M. C. O., Mccormick, M. I., Munday, P. L., Meekan, M. G., Dixson, D. L., Lönnstedt, O., et al. (2012). Effects of ocean acidification on visual risk assessment in coral reef fishes. Funct. Ecol. 26, 553-558. doi: 10.1111/j.13652435.2011.01951.x

Fine, M., and Tchernov, D. (2007). Scleractinian coral species survive and recover from decalcification. Science 315:1811. doi: 10.1126/science.1137094

Firestein, S. (2001). How the olfactory system makes sense of scents. Nature 413, 211-218. doi: 10.1038/35093026

Form, A. U., and Riebesell, U. (2012). Acclimation to ocean acidification during long-term $\mathrm{CO}_{2}$ exposure in the cold-water coral Lophelia pertusa. Globel Change Biol. 18, 843-853. doi: 10.1111/j.1365-2486.2011.02583.x

Gardiner, J. M., Atema, J., Hueter, R. E., and Motta, P. J. (2014). Multisensory integration and behavioral plasticity in sharks from different ecological niches. PLoS One 9:e93036. doi: 10.1371/journal.pone.0093036

Gazeau, F., Gattuso, J. P., Dawber, C., Pronker, A. E., Peene, F., Peene, J., et al. (2010). Effect of ocean acidification on the early life stages of the blue mussel Mytilus edulis. Biogeosci. Discuss. 7, 2051-2060. doi: 10.5194/bg-7-2051-2010

Gravinese, P. M. (2017). Ocean acidification impacts the embryonic development and hatching success of the Florida stone crab, Menippe mercenaria. J. Exp. Mar. Biol. Ecol. 500, 140-146. doi: 10.1016/j.jembe.2017.09.001

Havenhand, J. N., Buttler, F., Thorndyke, M. C., and Williamson, J. E. (2008). Nearfuture levels of ocean acidification reduce fertilization success in a sea urchin. Curr. Biol. 18, R651-R652. doi: 10.1016/j.cub.2008.06.015

Heuer, R. M., and Grosell, M. (2014). Physiological impacts of elevated carbon dioxide and ocean acidification on fish. Am. J. Physiol.-Regul. I 307, R1061R1084. doi: 10.1152/ajpregu.00064.2014

Heuer, R. M., Welch, M. J., Rummer, J. L., Munday, P. L., and Grosell, M. (2016). Altered brain ion gradients following compensation for elevated $\mathrm{CO}_{2}$ are linked to behavioural alterations in a coral reef fish. Sci. Rep. 6:33216. doi: 10.1038/ srep33216

Hofmann, L. C., and Bischof, K. (2014). Ocean acidification effects on calcifying macroalgae. Aquat. Biol. 22, 261-279. doi: 10.3354/ab00581

Ishimatsu, A., Kikkawa, T., Hayashi, M., Lee, K. S., and Kita, J. (2004). Effects of $\mathrm{CO}_{2}$ on marine fish: larvae and adults. J. Oceanogr. 60, 731-741. doi: 10.1007/ s10872-004-5765-y
Ji, H., Om, A. D., Umino, T., Nakagawa, H., Sasaki, T., Okada, K., et al. (2003). Effect of dietary ascorbate fortification on lipolysis activity of juvenile black sea bream Acanthopagrus schlegeli. Fish. Sci. 69, 66-73. doi: 10.1046/j.1444-2906. 2003.00589.x

Kato, A., and Touhara, K. (2009). Mammalian olfactory receptors: pharmacology, G protein coupling and desensitization. Cell. Mol. Life Sci. 66, 3743-3753. doi: 10.1007/s00018-009-0111-6

Kaupp, U. B. (2010). Olfactory signalling in vertebrates and insects: differences and commonalities. Nat. Rev. Neurosci. 11, 188-200. doi: 10.1038/nrn2789

Kleypas, A. J., Buddemeier, R. W., Archer, D., Gattuso, J. P., Langdon, C., and Opdyke, B. N. (1999). Geochemical consequences of increased atmospheric carbon dioxide on coral reefs. Science 284, 118-120. doi: 10.1126/science.284. 5411.118

Kroeker, K. J., Kordas, R. L., Crim, R., Hendriks, I. E., Ramajo, L., Singh, G. S., et al. (2013). Impacts of ocean acidification on marine organisms: quantifying sensitivities and interaction with warming. Global Change Biol. 19, 1884-1896. doi: $10.1111 /$ gcb.12179

Lai, F., Jutfelt, F., and Nilsson, G. E. (2015). Altered neurotransmitter function in $\mathrm{CO}_{2}$-exposed stickleback (Gasterosteus aculeatus): a temperate model species for ocean acidification research. Conserv. Physiol. 3:cov018. doi: 10.1093/ conphys/cov018

Lannig, G., Eilers, S., Pörtner, H. O., Sokolova, I. M., and Bock, C. (2010). Impact of ocean acidification on energy metabolism of oyster, Crassostrea gigaschanges in metabolic pathways and thermal response. Mar. Drugs 8, 2318-2339. doi: $10.3390 / \mathrm{md} 8082318$

Leduc, A. O., Munday, P. L., Brown, G. E., and Ferrari, M. C. (2013). Effects of acidification on olfactory-mediated behaviour in freshwater and marine ecosystems: a synthesis. Philos. T. R. Soc. B 368, 1-14. doi: 10.1098/rstb.2012. 0447

Liu, S., Plachez, C., Shao, Z., Puche, A., and Shipley, M. T. (2013). Olfactory bulb short axon cell release of GABA and dopamine produces a temporally biphasic inhibition-excitation response in external tufted cells. J. Neurosci. 33, 2916-2926. doi: 10.1523/JNEUROSCI.3607-12.2013

Liu, S., Shi, W., Guo, C., Zhao, X., Han, Y., Peng, C., et al. (2016). Ocean acidification weakens the immune response of blood clam through hampering the NF-kappa $\beta$ and toll-like receptor pathways. Fish Shellfish Immunol. 54, 322-327. doi: 10.1016/j.fsi.2016.04.030

Ma, J. J., Xu, Z. R., Shao, Q. J., Xu, J. Z., Hung, S. S. O., Hu, W. L., et al. (2008). Effect of dietary supplemental L-carnitine on growth performance, body composition and antioxidant status in juvenile black sea bream, Sparus macrocephalus. Aquacult. Nutr. 14, 464-471. doi: 10.1111/j.1365-2095.2007.00551.x

McMahon, S. J., Donelson, J. M., and Munday, P. L. (2018). Food ration does not influence the effect of elevated $\mathrm{CO}_{2}$ on antipredator behaviour of a reef fish. Mar. Ecol. Prog. 586, 155-165. doi: 10.3354/meps12397

Mehrbach, C., Culberson, C. H., Hawley, J. E., and Pytkowicx, R. M. (1939). Measurement of the apparent dissociation constants of carbonic acid in seawater at atmospheric pressure. Limnol. Oceanogr. 18, 897-907. doi: 10.4319/ lo.1973.18.6.0897

Miller, G. M., Watson, S. A., Donelson, J. M., McCormick, M. I., and Munday, P. L. (2012). Parental environment mediates impacts of increased carbon dioxide on a coral reef fish. Nat. Clim. Change 2, 858-861. doi: 10.1038/nclimate1599

Munday, P. L. (2014). Transgenerational acclimation of fishes to climate change and ocean acidification. F1000Prime Rep. 6:99. doi: 10.12703/P6-99

Munday, P. L., Dixson, D. L., Donelson, J. M., Jones, G. P., Pratchett, M. S., Devitsina, G. V., et al. (2009). Ocean acidification impairs olfactory discrimination and homing ability of a marine fish. Proc. Natl. Acad. Sci. U.S.A. 106, 1848-1852. doi: 10.1073/pnas.0809996106

Munday, P. L., Dixson, D. L., McCormick, M. I., Meekan, M., Ferrari, M. C. O., and Chivers, D. P. (2010). Replenishment of fish populations is threatened by ocean acidification. Proc. Natl. Acad. Sci. U.S.A. 107, 12930-12934. doi: 10.1073/pnas.1004519107

Munday, P. L., Pratchett, M. S., Dixson, D. L., Donelson, J. M., Endo, G. G. K., Reynolds, A. D., et al. (2013). Elevated $\mathrm{CO}_{2}$ affects the behavior of an ecologically and economically important coral reef fish. Mar. Biol. 160, $2137-$ 2144. doi: 10.1007/s00227-012-2111-6

Munday, P. L., Welch, M. J., Allan, B. J. M., Watson, S. A., McMahon, S. J., and McCormick, M. I. (2016). Effects of elevated $\mathrm{CO}_{2}$ on predator avoidance 
behaviour by reef fishes is not altered by experimental test water. PeerJ. 4:e2501. doi: $10.7717 /$ peerj.2501

Murphy, H. M., Warren-Myers, F. W., Jenkins, G. P., Hamer, P. A., and Swearer, S. E. (2014). Variability in size-selective mortality obscures the importance of larval traits to recruitment success in a temperate marine fish. Oecologia 175, 1201-1210. doi: 10.1007/s00442-014-2968-9

Nagelkerken, I., and Munday, P. L. (2016). Animal behaviour shapes the ecological effects of ocean acidification and warming: moving from individual to community-level responses. Global Change Biol. 22, 974-989. doi: 10.1111/gcb. 13167

Nilsson, G. E., Dixson, D. L., Domenici, P., McCormick, M. I., Sorensen, C., Watson, S., et al. (2012). Near-future carbon dioxide levels alter fish behavior by interfering with neurotransmitter function. Nat. Clim. Change 2, 201-204. doi: $10.1038 /$ nclimate 1352

Nip, T. H. M., Ho, W. Y., and Wong, C. K. (2003). Feeding ecology of larval and juvenile black sea bream (Acanthopagrus schlegeli) and japanese seaperch (Lateolabrax japonicas) in Tolo Harbour, Hong Kong. Environ. Biol. Fish. 66, 197-209. doi: 10.1023/A:1023611207492

Nowicki, J. P., Miller, G. M., and Munday, P. L. (2012). Interactive effects of elevated temperature and $\mathrm{CO}_{2}$ on foraging behavior of juvenile coral reef fish. J. Exp. Mar. Biol. Ecol. 412, 46-51. doi: 10.1016/j.jembe.2011.10.020

Orr, J. C., Fabry, V. J., Aumont, O., Bopp, L., Doney, S. C., Feely, R. A., et al. (2005). Anthropogenic ocean acidification over the twenty-first century and its impact on calcifying organisms. Nature 437, 681-686. doi: 10.1038/nature04095

Parker, L. M., Ross, P. M., and O'connor, W. A. (2009). The effect of ocean acidification and temperature on the fertilization and embryonic development of the sydney rock oyster Saccostrea glomerata (Gould 1850). Global Change Biol. 15, 2123-2136. doi: 10.1111/j.1365-2486.2009.01895.x

Parker, L. M., Ross, P. M., O'Connor, W. A., Borysko, L., Raftos, D. A., and Pörtner, H. (2012). Adult exposure influences offspring response to ocean acidification in oysters. Global Change Biol. 18, 82-92. doi: 10.1111/j.1365-2486. 2011.02520.x

Peng, C., Zhao, X., Liu, S., Shi, W., Han, Y., Guo, C., et al. (2016). Effects of anthropogenic sound on digging behavior, metabolism, Ca2+/Mg2+ ATPase activity, and metabolism-related gene expression of the bivalve, Sinonovacula constricta. Sci. Rep. 6:24266. doi: 10.1038/srep24266

Peng, C., Zhao, X., Liu, S., Shi, W., Han, Y., Guo, C., et al. (2017). Ocean acidification alters the burrowing behaviour, $\mathrm{Ca} 2+/ \mathrm{Mg} 2+$ ATPase activity, metabolism, and gene expression of a bivalve species, Sinonovacula constricta. Mar. Ecol. Prog. Ser. 575, 107-117. doi: 10.3354/meps12224

Peterlin, Z., Firestein, S., and Rogers, M. E. (2014). The state of the art of odorant receptor deorphanization: a report from the orphanage. J. Gen. Physiol. 143, 527-542. doi: 10.1085/jgp.201311151

Pierrot, D., Lewis, E., Wallace, R., Wallace, D., Wallace, W., and Wallace, D. W. R. (2006). MS Excel Program Developed for $\mathrm{CO}_{2}$ System Calculations. Oak Ridge, TN: Carbon Dioxide Information Analysis Center.

Pistevos, J. C. A., Nagelkerken, I., Rossi, T., Olmos, M., and Connell, S. D. (2015). Ocean acidification and global warming impair shark hunting behavior and growth. Sci. Rep. 5:16293. doi: 10.1038/srep16293

Przeslawski, R., Byrne, M., and Mellin, C. (2015). A review and meta-analysis of the effects of multiple abiotic stressors on marine embryos and larvae. Global Change Biol. 21, 2122-2140. doi: 10.1111/gcb.12833

Regan, M. D., Turko, A. J., Heras, J., Andersen, M. K., Lefevre, S., Wang, T., et al. (2016). Ambient $\mathrm{CO}_{2}$, fish behaviour and altered GABAergic neurotransmission: exploring the mechanism of $\mathrm{CO}_{2}$-altered behaviour by taking a hypercapnia dweller down to low $\mathrm{CO}_{2}$ levels. J. Exp. Biol. 219, 109-118. doi: $10.1242 /$ jeb. 131375

Reuter, K. E., Lotterhos, K. E., Crim, R. N., Thompson, C. A., and Harley, C. D. G. (2011). Elevated $\mathrm{pCO}_{2}$ increases sperm limitation and risk of polyspermy in the red sea urchin, Strongylocentrotus franciscanus. Global Change Biol. 17, 163-171. doi: 10.1111/j.1365-2486.2010.02216.x

Roggatz, C. C., Lorch, M., Hardege, J. D., and Benoit, D. M. (2016). Ocean acidification affects marine chemical communication by changing structure and function of peptide signalling molecules. Global Change Biol. 22, 3914-3926. doi: $10.1111 /$ gcb.13354

Sabine, C. L., Feely, R. A., Gruber, N., Key, R. M., Lee, K., Bullister, J. L., et al. (2004). The oceanic sink for anthropogenic $\mathrm{CO}_{2}$. Science 305, 367-371. doi: 10.1126/science. 1097403
Saderne, V., and Wahl, M. (2012). Effect of ocean acidification on growth, calcification and recruitment of calcifying and non-calcifying epibionts of brown algae. Biogeosci. Discuss. 9, 3739-3766. doi: 10.5194/bgd-9-37392012

Schunter, C., Welch, M. J., Nilsson, G. E., Rummer, J. L., Munday, P. L., and Ravasi, T. (2018). An interplay between plasticity and parental phenotype determines impacts of ocean acidification on a reef fish. Nat. Ecol. Evol. 2, 334-342. doi: 10.1038/s41559-017-0428-8

Schunter, C., Welch, M. J., Ryu, T., Zhang, H., Berumen, M. L., Nilsson, G. E., et al. (2016). Molecular signatures of transgenerational response to ocean acidification in a species of reef fish. Nat. Clim. Change 6, 1014-1018. doi: 10.1038/NCLIMATE3087

Segman, R. F., Dubinsky, Z., and Iluz, D. (2016). Impacts of ocean acidification on calcifying macroalgae: Padina sp. as a test case-a review. ISR J. Plant. Sci. 65, 1-8. doi: 10.1080/07929978.2016.1237491

Sewell, M. A., Millar, R. B., Yu, P. C., Kapsenberg, L., and Hofmann, G. E. (2013). Ocean acidification and fertilization in the Antarctic sea urchin Sterechinus neumayeri: the importance of polyspermy. Environ. Sci. Technol. 48, 713-722. doi: 10.1021/es402815s

Shi, W., Han, Y., Guo, C., Zhao, X., Liu, S., Su, W., et al. (2017a). Ocean acidification hampers sperm-egg collisions, gamete fusion, and generation of $\mathrm{Ca} 2+$, oscillations of a broadcast spawning bivalve, Tegillarca granosa. Mar. Environ. Res. 170, 106-112. doi: 10.1016/j.marenvres.2017. 07.016

Shi, W., Zhao, X., Han, Y., Guo, C., Liu, S., Su, W., et al. (2017b). Effects of reduced $\mathrm{pH}$ and elevated $\mathrm{pCO}_{2}$ on sperm motility and fertilization success in blood clam, Tegillarca granosa. N. Z. J. Mar. Fresh. Res. 51, 543-554. doi: 10.1080/00288330.2017.1296006

Su, W., Rong, J., Zha, S., Yan, M., Fang, J., and Liu, G. (2018). Ocean acidification affects the cytoskeleton, lysozymes, and nitric oxide of hemocytes: a possible explanation for the hampered phagocytosis in blood clams, Tegillarca granosa. Front. Physiol. 9:619. doi: 10.3389/fphys.2018.00619

Su, W., Zha, S., Wang, Y., Shi, W., Xiao, G., Chai, X., et al. (2017). Benzo[a]pyrene exposure under future ocean acidification scenarios weakens the immune responses of blood clam, Tegillarca granosa. Fish Shellish Immunol. 63, 465472. doi: $10.1016 /$ j.fsi.2017.02.046

Tallarida, R. J., and Murray, R. B. (1987). Duncan Multiple Range Test. Manual of Pharmacologic Calculations. New York, NY: Springer.

Tatti, R., Bhaukaurally, K., Gschwend, O., Seal, R. P., Edwards, R. H., Rodriguez, I., et al. (2014). A population of glomerular glutamatergic neurons controls sensory information transfer in the mouse olfactory bulb. Nat. Commun. 5:3791. doi: $10.1038 /$ ncomms4791

Team, C. W., Pachauri, R. K., and Meyer, L. A. (2014). Climate change 2014: synthesis report. contribution of working groups i, ii and iii to the fifth assessment report of the intergovernmental panel on climate change. J. Romance Stud. 4, 85-88.

Wang, Q., Cao, R., Ning, X., You, L., Mu, C., Wang, C., et al. (2016). Effects of ocean acidification on immune responses of the Pacific oyster Crassostrea gigas. Fish Shellfish Immunol. 49, 24-33. doi: 10.1016/j.fsi.2015.12.025

Welch, M. J., Watson, S. A., Welsh, J. Q., McCormick, M. I., and Munday, P. L. (2014). Effects of elevated $\mathrm{CO}_{2}$ on fish behaviour undiminished by transgenerational acclimation. Nat. Clim. Change 4, 1086-1089. doi: 10.1038/ nclimate 2400

Widdicombe, S., and Spicer, J. I. (2008). Predicting the impact of ocean acidification on benthic biodiversity: what can animal physiology tell us? J. Exp. Mar. Biol. Ecol. 366, 187-197. doi: 10.1016/j.jembe.2008.07.024

Wilsonleedy, J. G., and Ingermann, R. L. (2007). Development of a novel CASA system based on open source software for characterization of zebrafish sperm motility parameters. Theriogenology 67, 661-672. doi: 10.1016/j.theriogenology. 2006.10.003

Wittmann, A. C., and Pörtner, H. O. (2013). Sensitivities of extant animal taxa to ocean acidification. Nat. Clim. Change 3, 995-1001. doi: 10.1038/ NCLIMATE1982

Yopak, K. E., Lisney, T. J., and Collin, S. P. (2015). Not all sharks are "swimming noses": variation in olfactory bulb size in cartilaginous fishes. Brain Struct. Funct. 220, 1127-1143. doi: 10.1007/s00429-014-0705-0

Zhao, L., Schöne, B. R., Mertz-Kraus, R., and Yang, F. (2016). Sodium provides unique insights into transgenerational effects of ocean acidification on bivalve 
shell formation. Sci. Total Environ. 577, 360-366. doi: 10.1016/j.scitotenv.2016. 10.200

Zhao, L., Yang, F., Milano, S., Han, T., Walliser, E. O., and Schöne, B. R. (2018). Transgenerational acclimation to seawater acidification in the manila clam Ruditapes philippinarum: preferential uptake of metabolic carbon. Sci. Total Environ. 627, 95-103. doi: 10.1016/j.scitotenv.2018.01.225

Zhao, X., Guo, C., Han, Y., Che, Z., Wang, Y., Wang, X., et al. (2017a). Ocean acidification decreases mussel byssal attachment strength and induces molecular byssal responses. Mar. Ecol. Prog. Ser. 565, 67-77. doi: 10.3354/ meps 11992

Zhao, X., Shi, W., Han, Y., Liu, S., Guo, C., Fu, W., et al. (2017b). Ocean acidification adversely influences metabolism, extracellular $\mathrm{pH}$ and calcification of an economically important marine bivalve, Tegillarca granosa. Mar. Environ. Res. 125, 82-89. doi: 10.1016/j.marenvres.2017.01.007
Conflict of Interest Statement: HM was employed by company Lucta (Guangzhou) Flavors Co., Ltd.

The remaining authors declare that the research was conducted in the absence of any commercial or financial relationships that could be construed as a potential conflict of interest.

Copyright (C) 2018 Jiahuan, Wenhao, Xiaofan, Wei, Shanjie, Maolong, Haifeng and Guangxu. This is an open-access article distributed under the terms of the Creative Commons Attribution License (CC BY). The use, distribution or reproduction in other forums is permitted, provided the original author(s) and the copyright owner(s) are credited and that the original publication in this journal is cited, in accordance with accepted academic practice. No use, distribution or reproduction is permitted which does not comply with these terms. 